\title{
Involvement in Subject Teachers Association (MGMP), Pedagogical and Professional Competencies of Civic Teachers, And Learning Outcomes: A Correlational Study
}

\author{
Auliah Safitri ${ }^{1 *}$, Abdul Gafur \\ Universitas Negeri Yogyakarta, Jl. Colombo No. 1, Yogyakarta 55281 \\ Iauliahsyafitri@yahoo.com \\ *corresponding author
}

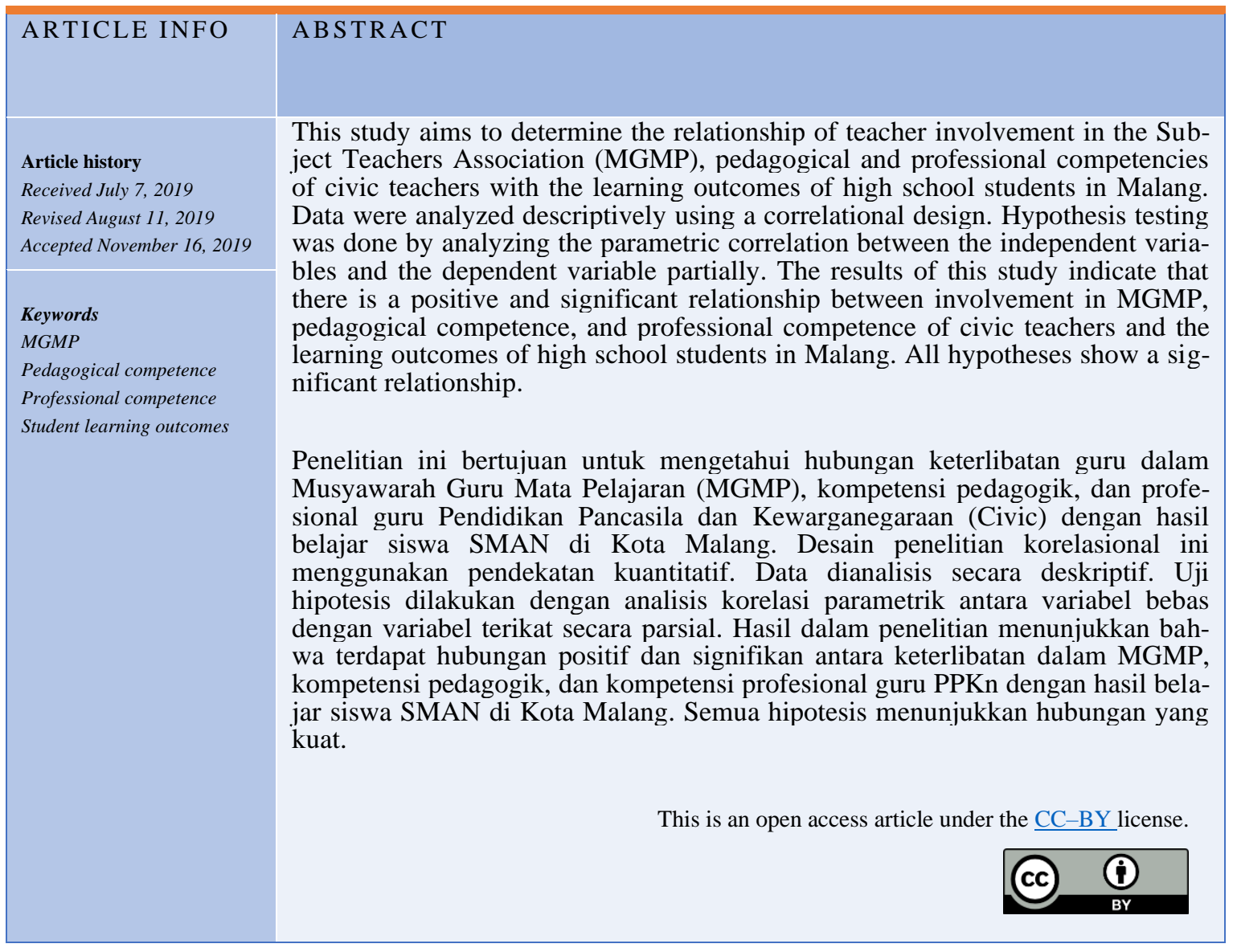

\section{Introduction}

National development in the field of education is an effort to educate the nation's life and improve the quality of Indonesian people. One factor that has a strategic role in the field of education is the teacher. The problem of teachers in Indonesia is directly or indirectly related to their professionalism, which is still inadequate. Whereas the teacher's position as a professional serve to improve the dignity and role of the teacher as an agent of learning that can improve the quality of national education.

Based on UNESCO data in (Global Education Monitoring, 2019) Report, education in Indonesia ranks 10th out of 14 developing countries, and teacher quality ranks 14th out of 14 developing countries in the world. Teachers in carrying out their duties as educators and instructors tested professionalism with the Teacher Competency Test (UKG). Competencies tested are teacher's pedagogical and professional competencies. Sumarna Surapranata, as Director General of Teachers and Education Personnel (GTK) said that the national average UKG results for pedagogical competencies were only 48.94 . These results are below the minimum competency standard (SKM) 55 .

Various teacher professionalism programs are designed to improve student learning out- 
comes because teachers have the greatest impact on student achievement (Swanson \& Ritter, 2018). As stated by (Shuls, J, 2018), to improve student achievement, policymakers must find ways to help improve the quality of the teaching profession. Teacher involvement in Subject Teachers Association (MGMP) is seen as being able to improve pedagogical competence. The development of teacher professionalism requires a forum for cooperation that gives authority and the availability of time to hold meetings in carrying out professional assignments. One of the MGMP activities is classroom supervision carried out by the core teacher (instructor) and is a form of peer supervision carried out in groups with a collaborative orientation. Through MGMP activities, teachers will be able to improve their abilities in the learning process. All forms of difficulties encountered in the field will be easy to find solutions from MGMP participant teachers and supervisors.

The facts found in the field show that the work of MGMP in the high school level, in general, has not run optimally as expected. Even in some places, MGMP is not running at all. It also generally describes the MGMP. It is suspected that the condition influenced the learning outcomes of civic. The rationale for teacher involvement in MGMP activities can improve the professional and pedagogical competence of civic teachers.

\section{Method}

The populations in this study were 19 civic teachers who came from the seven senior high schools. The seven high schools are SMAN 1, SMAN 2, SMAN 4, SMAN 7, SMAN 8, SMAN 9, and SMAN Taruna Nala East Java, while the population of class X and XI students taught by teachers in these seven high schools is 4,458 students. The determination of the teacher sample employed a saturated sample technique because all members of the teacher population were used as samples. To determine student samples, researchers refer to Krejcie and Morgan's tables. If the population is 4,458 with a significance level of $5 \%$, the total sample is 354 students.

Data collection methods used in this study was questionnaire and test. Questionnaires were given to teachers that were used to obtain data on Subject Teachers Association in the MGMP, pedagogical competence, and teacher professionalism. The test is used to measure students' cognitive abilities. Making test ques- tions refers to the revised edition of the 2013 Curriculum 2013. The validity test was carried out before the data collection of 14 teachers, 25 students of class X, and 25 students of class XI, which were calculated by the SPSS 16 . The reliability test was carried out with reference to the Cronbach Alpha value if the Cronbach Alpha value> 0.60 , the reliability of questions/statements can be accepted.

The data analysis technique was done using descriptive analysis, prerequisite test, and hypothesis test. The data description includes the Mean (M), Median (Me), Mode (Mo), and Standard Deviation (SDi) values. The prerequisite test consists of a normality test. The normality test in this study used the One-Sample Kolmogorov-Smirnov test with a significance level of 0.05 to determine the normal population distribution or not. Hypothesis testing in this study uses correlation analysis to find the relationship between the two variables and the direction of the relationship. The correlation coefficient range is from 1 to -1 , a value as close as 1 or -1 means that the relationship between two variables is stronger, on the contrary, a value close to 0 means that the relationship between the two variables is getting weaker. The type of correlation used is the correlation of two variables because, in this study, independent variables and dependent variables have been determined.

\section{Results and Discussion}

\section{A. The Relationship of Civic Teacher Involvement in MGMP with Student Learning Outcomes}

The first hypothesis is: "The involvement of civic teachers in MGMP has a relationship with the learning outcomes of high school students in Malang." This first hypothesis was tested using a two-variable correlation analysis. With the help of the Statistics program (SPSS) for windows 16 a summary of the results of the correlation analysis of two variables is obtained in table 1.

Table 1 illustrates the magnitude of the correlation coefficient of civic Subject Teachers Association in MGMP with student learning outcomes is 0.697 at a significance level of 0.001 . R-count value of 0.697 shows that there is a strong relationship between the involvements of civic teachers in MGMP with student learning outcomes. While the direction of the relationship is positive because the value of $r$ arithmetic is positive, the higher the involve- 
ment of civic teachers in the MGMP, the more student learning outcomes increase. R-count value of 0.697 at the level of probability (confidence) $0.05(95 \%)$ obtained r-table 0.433 (using the r-table guide).

Table 1. Hypothesis Testing I

\begin{tabular}{|c|c|c|c|}
\hline & & $\begin{array}{l}\text { Involve- } \\
\text { ment in } \\
\text { MGMP } \\
\text { (X1) }\end{array}$ & $\begin{array}{c}\text { Stu- } \\
\text { dents' } \\
\text { Learning } \\
\text { Out- } \\
\text { comes } \\
\text { (Y) }\end{array}$ \\
\hline $\begin{array}{c}\text { Involveme } \\
\text { nt in } \\
\text { MGMP } \\
\text { (X1) }\end{array}$ & $\begin{array}{c}\text { Pearson } \\
\text { Correlatio } \\
n \\
\text { Sig. }(2- \\
\text { tailed) } \\
\mathrm{N}\end{array}$ & 1 & $.697^{* *}$ \\
\hline $\begin{array}{c}\text { Students' } \\
\text { Learning } \\
\text { Outcomes } \\
\text { (Y) }\end{array}$ & $\begin{array}{c}\text { Pearson } \\
\text { Correlatio } \\
\mathrm{n} \\
\text { Sig. (2- } \\
\text { tailed) } \\
\mathrm{N}\end{array}$ & $\begin{array}{c}.001 \\
19\end{array}$ & 19 \\
\hline
\end{tabular}

The results of the study prove that the involvement of civic teachers in MGMP has a relationship with student learning outcomes. This means that the program to improve teacher qualifications through MGMP needs to be carried out on an ongoing basis. Teachers must be able to develop their qualities by involving themselves in MGMP activities continuously. This is in accordance with the opinion of (Minarni \& Triyaningsih, 2011) that the success of teacher performance is influenced by several factors including a conducive work climate, education, guidance, and guidance system that is carried out through supervision, welfare/salary, participation in upgrading, participation in the activities of the Eye Teacher Consultation Lessons (MGMP), facilities that can support teaching success, discipline, and motivation, as well as the principal's leadership style. However, there are still other factors that influence, for example, gender and work culture.

One that is expected to be the improvement in professionalism and teaching performance is owned by teachers who teach in public schools. This increase was a result of their involvement in MGMP activities. This institution is a place that can improve the professionalism and performance of teachers (Anwar, 2011).

Changes in education require changes in teacher beliefs, attitudes, and values. That is why there is a need for teacher development
(Jimenez Raya \& Sercu, 2007) because teacher development is a process of continuous growth, intellectual, experience, and attitude (Lange, 1983). According to (Marno \& Idris, 2010) improvement of teacher professional abilities can be done in various ways such as further education in the position and the establishment of forums for improving the quality of teachers such as supervision, Teacher Work Strengthening (PKG), and Subject Teachers Association (MGMP). These activities aim to enable teachers to develop and improve their quality, both in terms of knowledge and skills in teaching.

Teachers will become more professional if they take a more active role in developing their work methods and curriculum and collaborating with other personnel in the education system so that school efficiency and productivity will increase (Ringarp, 2012). Teachers also have the autonomy to be active and involved in dialogue with teachers and other administrators, so they can discuss the ideas they have (Naylor, 2015). In addition, (Hartiningtyas \& Elmunsyah, 2016) also revealed that professional teachers must always adjust to the times, requiring teachers to be always up-to-date with the latest technology.

(Long et al., 2017) call teacher collaboration called the teacher union seen as a steppingstone in improving the quality of education. According to him, the teacher union is considered to protect members who have insufficient knowledge content and have poor performance because teachers as state servants should be able to implement the curriculum well.

\section{B. Correlation between teachers' pedagogic competence and students' learning outcomes}

The second hypothesis states that the civic teacher's pedagogical competence has a relationship with the learning outcomes of high school students in Malang. This second hypothesis was tested using a two-variable correlation analysis. With the help of the Statistical Program (SPSS) for windows 16 a summary of the results of the correlation analysis of two variables is obtained in Table 2. Table 2 illustrates the magnitude of the coefficient correlation of teacher civic pedagogical competencies with student learning outcomes is 0.645 at a significance level of 0.003 . The r-count value of 0.645 indicates that there is a strong relationship between the civic teacher's pedagogical competencies and student learning outcomes. A positive r-count value means that the higher the pedagogical competence of civic teachers, the 
more student learning outcomes will increase. R-count value of 0.645 at the level of probability (confidence) 0.05 (95\%) obtained r-table 0.433 (using the r-table guide).

Table 2. Hypothesis Testing II

\begin{tabular}{|c|c|c|c|}
\hline & & $\begin{array}{c}\text { Pedagogic } \\
\text { Compe- } \\
\text { tence (X2) }\end{array}$ & $\begin{array}{c}\text { Stu- } \\
\text { dents' } \\
\text { Learning } \\
\text { Out- } \\
\text { comes } \\
(Y)\end{array}$ \\
\hline \multirow{4}{*}{$\begin{array}{c}\text { Pedagogic } \\
\text { Competenc } \\
\text { e (X2) }\end{array}$} & Pearson & 1 & $.645 * *$ \\
\hline & $\begin{array}{c}\text { Correlatio } \\
\mathrm{n}\end{array}$ & & \\
\hline & $\begin{array}{l}\text { Sig. (2- } \\
\text { tailed) }\end{array}$ & & .003 \\
\hline & $\mathrm{N}$ & 19 & 19 \\
\hline \multirow{5}{*}{$\begin{array}{c}\text { Students' } \\
\text { Learning } \\
\text { Outcomes } \\
\text { (Y) }\end{array}$} & Pearson & $.645 * *$ & 1 \\
\hline & Correlatio & & \\
\hline & $\mathrm{n}$ & & \\
\hline & $\begin{array}{l}\text { Sig. (2- } \\
\text { tailed) }\end{array}$ & .003 & 1 \\
\hline & $\mathrm{N}$ & 19 & 19 \\
\hline
\end{tabular}

The results of the study indicate that the teacher's pedagogical competence has a relationship with student learning outcomes. Therefore, it is important for teachers to be able to develop their pedagogical competencies as one indicator of pedagogical competence is the use of learning technology.

The results of this study are supported by research conducted by (Weschke et al., 2011) with teachers as research objects trained to apply online learning. The results of the study state that the full online program aimed at training teachers can provide opportunities for teachers to gain knowledge of pedagogical content that can positively influence teaching effectiveness.

The connection between technology implementation and pedagogical decisions is essential for teaching and learning who want to move towards transformation. Using special technology to enhance learning through deliberate pedagogical decisions is the foundation for professional development for transformative practices of the twenty-first century (Angeli \& Valanides, 2014).

It is undeniable that teachers still have a limited understanding of the internet, especially about teaching certain content using web technology. Therefore it is crucial to provide courses to teachers (Kale, 2014; Koh \& Chai, 2015; Kumar \& Vigil, 2011). Teachers also have an important role in providing efficient content that is developed in the form of technology (Southall, 2013).

Research conducted by (Davies et al., 2013) informed that there is a significant relationship between elements of the physical and pedagogical environment with an increase in student learning outcomes. They concluded, structuring the physical and pedagogical environment of teachers will have an impact on students.

\section{Correlation between teachers' professional competence and students' learning outcomes}

The third hypothesis states that the professional competencies of civic teachers have a relationship with the learning outcomes of high school students in Malang. This third hypothesis was tested using a two-variable correlation analysis. With the help of the Statistics program (SPSS) for windows 16 a summary of the results of the correlation analysis of two variables is obtained in Table 3.

Table 3. Hypothesis Testing III

\begin{tabular}{|c|c|c|c|}
\hline & & $\begin{array}{c}\text { Professiona } \\
1 \\
\text { Competenc } \\
\text { e (X3) } \\
\end{array}$ & $\begin{array}{c}\text { Students' } \\
\text { Learning } \\
\text { Outcome } \\
\text { s (Y) }\end{array}$ \\
\hline \multirow{3}{*}{$\begin{array}{c}\text { Professiona } \\
1 \\
\text { Competenc } \\
\text { e (X3) }\end{array}$} & $\begin{array}{c}\text { Pearson } \\
\text { Correlatio }\end{array}$ & 1 & $.624 * *$ \\
\hline & $\begin{array}{l}\text { n } \\
\text { Sig. }(2- \\
\text { tailed) }\end{array}$ & & .005 \\
\hline & $\mathrm{N}$ & 19 & 19 \\
\hline \multirow{3}{*}{$\begin{array}{c}\text { Students' } \\
\text { Learning } \\
\text { Outcomes } \\
\text { (Y) }\end{array}$} & $\begin{array}{c}\text { Pearson } \\
\text { Correlatio } \\
\text { n }\end{array}$ & $.624 * *$ & 1 \\
\hline & $\begin{array}{l}\text { Sig. (2- } \\
\text { tailed) }\end{array}$ & .005 & 1 \\
\hline & $\mathrm{N}$ & 19 & 19 \\
\hline
\end{tabular}

Table 3 illustrates the magnitude of the correlation coefficient of professional competence of civic teachers with student learning outcomes is 0.624 at a significance level of 0.005 . The r-count value of 0.624 indicates that there is a strong relationship between the professional competencies of civic teachers and student learning outcomes. While the direction of the relationship is positive because the value of $r$ arithmetic is positive, meaning that the higher the pedagogical competence of civic teachers, the more student learning outcomes increase. R-count value of 0.624 at the level of probability (confidence) 0.05 (95\%) obtained r-table 0.433 (using the r-table guide).

The results of the study are related to the research of (Chang \& Kuo, 2011), who observed 
five trends in professional teaching standards. First, developing teacher professional standards is a long-term investment that involves a lot of human resources. Second, the field of teaching research has transformed traditional teacher effectiveness research into constructivism research. Third, although the teacher's professional standards focus on curriculum, teaching and classroom management, other professional teacher activities, such as student counseling, teaching reflection, learning communities, and professional responsibilities, take into general account teaching. Fourth, these standards emphasize teacher teaching but ultimately consider student learning processes and outcomes. Fifth, it tends to develop general core standards for various disciplines and stages of learning and then to develop standards for specific subjects and stages of learning

In general, student learning outcomes are influenced by internal and external factors. Internal factors include physiological aspects (body fitness and sensory conditions) and psychological aspects (intelligence, attitudes, talents, interests, motivation, and personality). While external factors that can affect student learning outcomes include social (friends, teachers, family, and community) and nonsocial environment (conditions of the home, school, equipment, nature/weather). One factor that is the focus of this study is the external social environment, the teacher. Teacher involvement in MGMP, pedagogical competence, and teacher professional competence has been proven to have a relationship with the learning outcomes of high school students in Malang.

Teachers who have professional competence must be able to sort and select and group learning materials that will be delivered to students according to their type. Without ignoring other competencies, professional competence is a competency that must be possessed by professional teachers. Striving for professionalism is not seen as a condition but as a goal.

Teacher professional development is driven by the need to expand and renew teacher practices, skills, and beliefs. Stimuli for such needs could be due to changes in curriculum, new classroom technology, advances in pedagogy, or all of them. However, the underlying effort is to improve outcomes for students, whether they are focused on understanding, skills, attitudes, or involvement (Doig \& Groves, 2011).

(Avalos, 2011) argues that professional development is about teacher learning, learning how to learn, and turning their knowledge into practices for the benefit of student growth. Recommended activities to support teacher professional competence include examining data about student progress, analyzing student work, determining effective strategies to facilitate learning, designing and critiquing strong lessons, and developing class-based general assessments to measure progress (Mindich \& Lieberman, 2012). This activity is recommended to focus the teacher's attention on student performance in their classrooms. (Stewart, 2014) also suggests that teachers can develop professional learning projects targeted in lessons when they can take the time to investigate the work done by their students.

From the results of data analysis that has been done, the authors recommend that teacher involvement in the MGMP is the most important factor in improving student learning outcomes. This is consistent with the results of the effective contribution, which shows that the involvement of teachers in the MGMP is $30.94 \%$ greater than the effective contribution of teacher pedagogical competencies by $23.15 \%$ and professional teacher competencies by $25.14 \%$. Teacher involvement in MGMP can help teachers in solving problems faced by teachers in the classroom to improve student learning outcomes.

According to (Ciaccio et al., 2017), in 2007, New York changed its teacher evaluation system with the first step being to develop a teacher evaluation system that links teacher accountability to student learning outcomes because it mandates teacher evaluation based on student data analysis and evaluation systems needed throughout the country the part that connects teacher accountability with student learning outcomes. Based on the results of research conducted by (Shuls, J, 2018), students who have very effective teachers will have high learning outcomes. Besides, highly effective teachers also contribute to better life outcomes for their students.

\section{Conclusion}

From the results of research that has been done, the authors can draw the following conclusions. First, there is a positive and significant relationship between the involvements of civic teachers in MGMP with student learning outcomes. Secondly, there is a positive and significant relationship between the civic teacher's pedagogical competencies and student learning outcomes. Third, there is a positive 
and significant relationship between the professional competencies of civic teachers and learning outcomes.

Based on the conclusions of the above results, it can be stated that some suggestions are expected to provide consideration. First, teachers must be active in MGMP activities programs, both routine programs, and development programs, that can improve pedagogical and professional competence. Second, teachers must further enhance their pedagogical competencies, for example, better understand student characters, develop curriculum well, and improve the use of information and communication technology, and other pedagogical competencies. Third, teachers need to enhance their professional competence further. Some indicators of professional competency, for example, are more knowledgeable about the material delivered to students, can adjust the material to the needs of students, and can use and develop various tools, methods, and learning resources accordingly. Various tools, methods, and learning resources are more relevant to be applied with a variety of variations because of the ability of students, and the way they understand the subject matter also varies.

\section{References}

Angeli, C., \& Valanides, N. (2014). Technological pedagogical content knowledge: Exploring, developing, and assessing TPCK. Springer.

Anwar, R. (2011). Pengaruh musyawarah guru mata pelajaran (MGMP) terhadap peningkatan profesionalisme dan kinerja mengajar guru sma negeri kota tasikmalaya. Jurnal administrasi pendidikan, 13(1).

Avalos, B. (2011). Teacher professional development in teaching and teacher education over ten years. Teaching and teacher education, 27(1), 10-20.

Chang, D. R., \& Kuo, S. F. (2011). Problems and prospects of the practice and research of teacher professional development in Taiwan. Journal of teacher education and teacher professional development, 4(2), 21-44.

Ciaccio, A., DeMaio, R., Flynn, A., Hanssler, S., Malone, M., Mare, S., Santiago, G., \& Short, V. (2017). Report: Tying teacher evaluation to student test performance in New York State.

Davies, D., Jindal-Snape, D., Collier, C., Digby, R., Hay, P., \& Howe, A. (2013). The impact of creative learning environments on learners: a systematic literature review. Improving schools, 16(1), 21-31.
Doig, B., \& Groves, S. (2011). Japanese lesson study: Teacher professional development through communities of inquiry. Mathematics teacher education and development, 13(1), 77-93.

Global Education Monitoring. (2019). United nations of educational, scientific, and cultural organization.

Hartiningtyas, L., \& Elmunsyah, H. (2016). Meningkatkan kompetensi pedagogik dan profesional guru smk melalui pemberdayaan pengembangan keprofesian berkelanjutan (PKB).

Jimenez Raya, M., \& Sercu, L. (2007). Challenges in teacher development: learner autonomy and intercultural competence. Foreign language teaching in europe. Volume 10. ERIC.

Kale, U. (2014). Can they plan to teach with Web 2.0? Future teachers' potential use of the emerging web. Technology, pedagogy and education, 23(4), 471-489.

Koh, J. H. L., \& Chai, C. S. (2015). Towards a Web 2.0 TPACK lesson design framework: applications of a Web 2.0 TPACK survey of Singapore preservice teachers. In New media and learning in the 21st century (pp. 161-180). Springer.

Kumar, S., \& Vigil, K. (2011). The net generation as preservice teachers: Transferring familiarity with new technologies to educational environments. Journal of digital learning in teacher education, 27(4), 144-153.

Lange, D. L. (1983). Teacher development and certification in foreign languages: where is the future? The modern language journal, 67(4), 374-381.

Long, C., Graven, M., Sayed, Y., \& Lampen, E. (2017). Enabling and constraining conditions of professional teacher agency: The South African context. Contemporary Education Dialogue, 14(1), 5-21.

Marno \& Idris, M. (2010). Strategi \& metode pengajaran: Menciptakan ketrampilan mengajar yang efektif dan edukatif. Yogyakarta: Ar-Ruzz Media.

Minarni, S., \& Triyaningsih, S. (2011). Pengaruh disiplin, bimbingan dan kegiatan mgmp terhadap kinerja guru smp negeri 1 tawagharjo kabupaten grobongan. Manajemen sumberdaya manusia, 5(1), $11-22$.

Mindich, D., \& Lieberman, A. (2012). Building a learning community: a tale of two schools. Stanford center for opportunity policy in education.

Naylor, C. (2015). Professional learning: What does the research say? (Vol. 27, Issue 3). British Columbia Teacher's Federation.

Ringarp, J. (2012). The problem of the welfare profession: an example-the 
municipalisation of the teaching profession. Policy futures in education, 10(3), 328-339.

Shuls, J, V. (2018). Raising the bar on teacher quality: Assessing the impact of increasing licensure exam cut-scores. Educational policy, 32(7), 969-992.

Southall, S. P. (2013). Digital natives preservice teachers: An examination of their selfefficacy beliefs regarding technology integration in classroom settings. Society for information technology \& teacher education international conference, 14281434.
Stewart, C. (2014). Transforming professional development to professional learning. Journal of adult education, 43(1), 28-33.

Swanson, E., \& Ritter, G. (2018). Using classroom observations and student surveys to evaluate alternatively certified teachers: a case study of the arkansas teacher corps. Journal of school leadership, 28(5), 642-670.

Weschke, B., Barclay, R. D., \& Vandersall, K. (2011). Online teacher education: exploring the impact of a reading and literacy program on student learning. Journal of asynchronous learning networks, 15(2), 22-43. 